\title{
ANALISIS PENGARUH KUALITAS PRODUK, HARGA, PROMOSI TERHADAP KEPUTUSAN PEMBELIAN AIR MINUM DALAM KEMASAN (AMDK) MEREK AICOS PRODUKSI PT. BUMI SARIMAS INDONESIA
}

\author{
Fetrizen, Nazaruddin Aziz \\ Sekolah Tinggi Ilmu Ekonomi "KBP” \\ nazaruddinaziz@akbpstie.ac.id
}

\begin{abstract}
Basically the decision to buy bottled water by consumers is influenced by many factors such as the quality of a product, brand, taste, lifestyle and the range of promotion made by the company. Driven by the needs that exist within a person and the desire that the needs in a person are affected if the consumer shows a sense of fun that ultimately leads to loyalty. Loyal customers are more valuable than customers who are just satisfied. For loyal customers will always use the product of all time and is a source of revenue and Aicos company in this case have been concerned about factors that can affect consumers in buying decisions. In this research, the research describes several variables that influence consumer purchase decision that is product quality, price, promotion. The quality of the product, the price, the promotion is called the independent variable and the purchase decision is called the dependent variable. Through the research results obtained by researchers, the researchers drew the conclusion that the variables free of price and promotion have a significant effect on purchasing decision because the value of sig <0,05. While for the independent variable of product quality has no significant effect with purchase decision because sig value > 0,05. This is because the consumers who have been interviewed stated that the drinking water products in their quality packaging are almost the same.
\end{abstract}

Keyword: Product Quality, Price, Promotion and Purchase Decision

\section{PENDAHULUAN}

Perusahaan harus bekerja keras membuat kebijakan- kebijakan strategis baru dalam menjual produk dan jasa mereka dalam kaitannya menghadapi persaingan yang ketat dengan competitor yang dapat memberikan value yang lebih besar kepada customer. Pada dasarnya dengan semakin banyaknya pesaing maka semakin banyak pula pilihan bagi pelanggan untuk dapat memilih produk yang sesuai dengan apayang menjadi harapannya.Sehingga konsekuensi dariperubahan tersebut adalah pelanggan menjadi lebih cermat dan pintar dalam menghadapi setiap produk yang diluncurkan di pasar.

Masyarakat kini mulai berpikir selektif dan smart dalam memilih suatu produk, sehingga mereka akan mendapatkan kegunaan atau manfaat yang mereka cari dari sebuah produk. Bahkan, terkadang mereka tidak ragu untuk 
mengeluarkan biaya lebih untuk mendapatkan produk yang berkualitas.Ketatnya persaingan akan memposisikan pemasar untuk selalu mengembangkan dan merebut marketshare.

Dari pengertian tersebut nampak bahwa perusahaan menjajaki apa yang diminta dan dibutuhkan oleh konsumen dan kemudian berusaha mengembangkan produk yang akan memuaskan konsumen sehingga menjadikan konsumen memiliki banyak alternatif pilihan produk sebelum mengambil keputusan untuk membeli suatu produk yang ditawarkan.

Banyak faktor yang mempengaruhi perilaku konsumen dalam keputusan pembelian barang dan jasa. Mempelajari dan menganalisa perilaku konsumen dalam keputusan pembelian adalah hal yang penting, sebab dengan pengetahuan dasar yang baik mengenai perilaku konsumen akan dapat memberikan masukan yang berarti bagi perencanaan strategi pemasaran

Strategi pemasaran terdiri dari unsur-unsur pemasaran yang terpadu (4P, yaitu product, price, promotion, place) yang selalu berkembang sejalan dengan gerak perusahaan dan perubahan-perubahan lingkungan pemasaran serta perubahan perilaku konsumen.Perilaku konsumen mempunyai implikasi sangat luas terhadap perumusan strategi pemasaran. Hal ini disebabkan karena strategi pemasaran menyangkut dua kegiatan pokok yang diantaranya adalah pemilihan pasar-pasar yang akan dijadikan sasaran pemasaran, serta merumuskan dan menyusun suatu kombinasi yang tepat dari marketing mix agar kebutuhan konsumen dapat dipenuhi secara memuaskan.

Bisnis Air Minum Dalam Kemasan (AMDK) semakin menggiurkan,karena kebutuhan akan air minum terus meningkat seiring dengan pertumbuhan penduduk. Perusahaan yang menggarap bisnis AMDK pun semakin banyak dan terus melakukan ekspansi untuk memperluas jaringan pasar produkproduknya.

Bayangkan saja, kebutuhan masyarakat akan air minum sangat tinggi. Padahal ketersediaan air yang layak minum dalam arti berkualitas dan terjamin dari segi kesehatan semakin sulit diperoleh. Saat ini masyarakat, terutama di kotakota besar tidak bisa lagi lepas dari AMDK.

Di samping tingginya akan permintaan air bersih, maka rendahnya hambatan untuk memasuki industri AMDK telah mengakibatkan pertumbuhan yang pesat dalam kemunculan perusahaan perusahaan yang baru. Pada saat ini tercatat ratusan merek produk AMDK yang beredar di seluruh Indonesia. Namun,ada 4 merek produksi AMDK di Sumatera Baratseperti Aicos, JJ, Aiya, dan Prima, dimana masing-masing menawarkan berbagai keunggulan. Dengan munculnya berbagai produk baru maupun penyempurnaan produk lama, para produsen semakin terpacu untuk menciptakan produk yang mampu bersaing dan mencoba untuk memenuhi keinginan dan selera konsumen.

Pada dasarnya keputusan membeli air minum dalam kemasan oleh konsumen dipengaruhi oleh banyak faktor antara lain mutu suatu produk, merek, selera, gaya hidup maupun jangkauan promosi yang dilakukan oleh perusahaan. Didorong oleh kebutuhan yang ada dalam diri seseorang dan keinginan bahwa kebutuhan dalam diri seseorang terpengaruh jika konsumen menunjukkan rasa senang yang pada akhirnya mengarah pada loyalitas.Pelanggan yang loyal lebih bernilai dari pada pelanggan yang hanya sekedar puas. Sebab pelanggan loyal akan selalu menggunakan produk sepanjang masa dan merupakan sumber 
pendapatan perusahaan dan Aicos dalam hal ini sudah memperhatikan faktorfaktor yang dapat mempengaruhi konsumen dalam keputusan membeli.

1. Keputusan Pembelian

Keputusan pembelian konsumen terhadap suatu produk pada dasarnya erat dengan perilaku konsumen. Perilaku konsumen merupakan unsur penting dalam kegiatan pemasaran suatu produk yang perlu diketahui oleh perusahaan, karena perusahaan pada dasarnya tidak mengetahui mengenai apa yang ada dalam pikiran seorang konsumen pada waktu sebelum, sedang, dan setelah melakukan pembelian produk tersebut.

Adanya kecenderungan pengaruh kualitas produk, harga dan promosi terhadap keputusan pembelian yang dilakukan oleh konsumen tersebut, mengisyaratkan bahwa manajemen perusahaan perlu mempertimbangkan aspek perilaku konsumen, terutama proses pengambilan keputusan pembeliannya.

Keputusan pembelian merupakan suatu proses pengambilan keputusan akan pembelian yang mencakup penentuan apa yang akan dibeli atau tidak melakukan pembelian dan keputusan itu diperoleh dari kegiatan-kegiatan sebelumnya (Sofjan Assauri,2004:141). Keputusan pembelian adalah sebuah pendekatan penyelesaian masalah pada kegiatan manusia untuk membeli suatu barang atau jasa dalam memenuhi keinginan dan kebutuhannya yang terdiri dari pengenalan kebutuhan dan keinginan, pencarian informasi, evaluasi terhadap alternatif pembelian, keputusan pembelian, dan tingkah laku setelah pembelian (Basu Swastha dan T Hani Handoko, 2000:15). Sedangkan menurut Philip Kotler (2000:251-252), yang dimaksud dengan keputusan pembelian adalah suatu proses penyelesaian masalah yang terdiri dari menganalisa atau pengenalan kebutuhan dan keinginan, pencarian informasi, penilaian sumber-sumber seleksi terhadap alternatif pembelian, keputusan pembelian, dan perilaku setelah pembelian.

Dari pengertian keputusan pembelian di atas dapat disimpulkan bahwa keputusan pembelian adalah perilaku pembelian seseorang dalam menentukan suatu pilihan produk untuk mencapai kepuasan sesuai kebutuhan dan keinginan konsumen yang meliputi pengenalan masalah, pencarian informasi, evaluasi terhadap alternatif pembelian, keputusan pembelian, dan perilaku setelah pembelian.

2. Kualitas Produk

Salah satu keunggulan dalam persaingan ini terutama adalah kualitas produk yang dapat memenuhi keinginan konsumen. Bila tidak sesuai dengan spesifikasi maka produk akan ditolak. Sekalipun produk tersebut masih dalam batas toleransi yang telah ditentukan maka produk tersebut sebaiknya perlu menjadi catatan untuk menghindari terjadinya kesalahan yang lebih besar diwaktu yang akan datang. Demikian juga konsumen dalam dalam membeli suatu produk konsumen selalu berharap agar barang yang dibelinya dapat memuaskan segala keinginan dan kebutuhannya.Untuk itu perusahaan harus dapat memahami keinginan konsumen, sehingga perusahaan dapat menciptakan produk yang sesuai dengan harapan konsumen.Kualitas produk yang baik merupakan harapan konsumen yang harus dipenuhi oleh perusahaan, karena kualitas produk yang baik merupakan kunci perkembangan produktivitas perusahaan.

Kualitas produk merupakan hal penting yang harus diusahakan oleh setiap perusahaan apabila menginginkan produk yang dihasilkan dapat bersaing di pasar. Dewasa ini, dikarenakan kemampuan ekonomi dan tingkat pendidikan masyarakat 
cenderung meningkat, sebagian masyarakat semakin kritis dalam mengkonsumsi suatu produk. Konsumen selalu ingin mendapatkan produk yang berkualitas sesuai dengan harga yang dibayar, walaupun terdapat sebagian masyarakat yang berpendapat bahwa, produk yang mahal adalah produk yang berkualitas.

Jika hal itu dapat dilaksanakan oleh perusahaan, maka perusahaan tersebut akan dapat tetap memuaskan para konsumen dan dapat menambah jumlah konsumen. Dalam perkembangan suatu perusahaan, persoalan kualitas produk akan ikut menentukan pesat tidaknya perkembangan perusahaan tersebut. Apabila dalam situasi pemasaran yang semakin ketat persaingannya, peranan kualitas produk akan semakin besar dalam perkembangan perusahaan. Selainitu, konsumen akan menyukai produk yang menawarkankualitas, kinerja, dan pelengkap inovatif yang terbaik (Lupiyoadi dan Hamdani,2006:131) Hal ini senada dengan pendapat dari Kotler dan Amstrong (2008) bahwa semakin baik kualitas produk yang dihasilkan maka akan memberikan kesempatan kepada konsumen untuk melakukan keputusan pembelian.

3. Harga

Harga merupakan salah satu faktor penting dari sisi penyedia jasa untuk memenangkan suatu persaingan dalam memasarkan produknya. Oleh karena itu harga harus ditetapkan . Menurut Augusty Ferdinand (2006), harga merupakan salah satu variabel penting dalam pemasaran, dimana harga dapat mempengaruhi konsumen dalam mengambil keputusan untuk membeli suatu produk, karena berbagai alasan. Alasan ekonomis akan menunjukkan harga yang rendah atau harga terlalu berkompetisi merupakan salah satu pemicu penting untuk meningkatkan kinerja pemasaran, tetapi alasan psikologis dapat menunjukkan bahwa harga justru merupakan indikator kualitas dan karena itu dirancang sebagai salah satu instrumen penjualan sekaligus sebagai instrument kompetisi yang menentukan.

Konsumen mempunyai anggapan adanya hubungan yang negatif antara harga dan kualitas suatu produk, maka mereka akan membandingkan antara produk yang satu dengan yang lainnya, dan barulah konsumen mengambil keputusan untuk membeli suatu produk.

Harga merupakan salah satu atribut penting yang dievaluasi oleh konsumen sehingga manajer perusahaan perlu benar-benar memahami peran tersebut dalam mempengaruhi sikap konsumen. Harga sebagai atribut dapat diartikan bahwa harga merupakan konsep keanekaragaman yang memiliki arti berbeda bagi tiap konsumen, tergantung karakteristik konsumen, situasi dan produk (Mowen dan Minor, 2002). Dengan kata lain, pada tingkat harga tertentu yang telah dikeluarkan, konsumen dapat merasakan manfaat dari produk yang telah dibelinya. Dan konsumen akan merasa puas apabila manfaat yang mereka dapatkan sebanding atau bahkan lebih tinggi dari nominal uang yang mereka keluarkan.

4. Promosi

Dalam mengelola suatu sistem komunikasi pemasaran memerlukan suatu rancangan strategi dan program-program penjualan yang efektif dan efisien.Promosi penjualan merupakan unsur kunci dalam kampanye perusahaan dan promosi yang paling baik adalah promosi yang dilakukan oleh pelanggan yang puas. Dengan demikian, promosi perlu ditangani secara cermat karena masalahnya bukan hanya menyangkut pada bagaimana berkomunikasi dengan 
pelanggan akan tetapi juga menyangkut seberapa besar biaya yang dikeluarkan untuk biaya ini yang tentunya harus disesuaikan pada kondisi dan kemampuan perusahan.

Promosi merupakan salah satu variabel di dalam marketing mix yang sangat penting dilaksanakan oleh perusahaan dalam pemasaran produk atau jasanya. Menurut Martin L. Bell dalam Swastha dan Irawan (2005:349) promosi adalah semua jenis kegiatan pemasaran yang ditujukan untuk mendorong permintaan. Promosi adalah arus informasi atau persuasi satu arah yang dibuat untuk mengarahkan seseorang atau organisasi kepada tindakan yang menciptakan pertukaran dalam pemasaran.

\section{METODE PENELITIAN}

\section{Populasi}

Populasi adalah gabungan dari seluruh elemen yang membentuk peristiwa, hal atau orang yang membentuk karakteristik yang serupa yang menjadi pusat perhatian peneliti karena itu dipandang sebagai sebuah semesta penelitian (Ferdinand, 2006). Populasi dari penelitian ini adalah konsumen Toko Bhakti Mart yang membeli Aicos

2. Sampel

Untuk melakukan sebuah penelitian, tidak harus diteliti keseluruhan anggota populasi yang ada.Sampel adalah subset dari populasi atau beberapa anggota dari populasi yang diamati (Ferdinand, 2006).

Dengan meneliti sebagian populasi, diharapkan dapat memperoleh hasil yang dapat menggambarkan sifat populasi yang bersangkutan.

\section{HASIL PENELITIAN}

\section{Gambaran Umum Penelitian}

Penelitian yang dilakukan ini bertujuan memberikan gambaran tentang pengaruh kualitas produk, harga dan promosi terhadap keputusan pembelian air dalam kemasan AICOS. Proses untuk mendapatkan data penelitan dilakukan melalui penyebaran kuesioner kepada para konsumen Bhakti Mart yang membeli produk AICOS.

Berdasarkan jenis kelamin menunjukkan bahwa jumlah responden laki-laki sebanyak 46,0\%, sementara untuk responden perempuan sebanyak 54,0\%. Hal ini menunjukkan bahwa konsumen perempuan lebih banyak yang melakukan pembelian minuman AICOS dibanding konsumen laki-laki.

Berdasarkan tabel 4.3 menunjukkan bahwa konsumen dengan kisaran umur 25 - 31 tahun jumlahnya lebih dominan sebanyak 38\%. Sedangkan untuk umur responden yang paling kecil persentasi dalam pengisian kuesioner adalah $<25$ tahun sebanyak $8 \%$.

Berdasarkan tabel 4.4 menunjukkan bahwa konsumen dengan jenis pekerjaannya wiraswasta adalah sebanyak $48 \%$ Sedangkan untuk pekerjaan yang persentasenya rendah adalah pelajar sebanyak 8\%. Maka dengan melihat tabel identifikasi pekerjaan responden dapat disimpulkan bahwa pekerjaan wiraswasta lebih dominan dari pekerjaan yang lainnya.

Berdasarkan tabel 4.5 menunjukkan bahwa konsumen dengan berpendapatan Rp 1.500.000 - 2.000.0000 adalah sebanyak 48\% Maka dengan melihat tabel 
identifikasi pendapatan responden dapat disimpulkan bahwa berpendapatan Rp 1.500.000 - 2.000.0000 lebih dominan dari pendapatan yang lainnya.

2. Uji Normalitas

Tujuan dari uji normalitas risidual adalah untuk menguji dalam sebuah model regresi, variabel dependen dan variabel independen terdistribusi secara normal atau tidak. Pengujian normalitas data dalam penelitian ini dilakukan dengan menggunakan one sample kolmogorov-smirnov test, yang mana jika nilai asymp.sig (2-tailed) > 0.05 maka distribusi data dikatakan normal.

Dari Tabel 4.18 terlihat bahwa nilai asymp.sig (2-tailed) menunjukkan nilai > dari 0.05, yaitu 0.942 Dengan demikian data dapat dikatakan berdistribusi normal. 3. Uji Heterokedastisitas

Dari Tabel 4.19 terlihat bahwa nilai sig menunjukkan nilai $>$ dari 0.05 , itu dapat diartikan tidak terjadi heteroskedasitas yang mana pada variabel X1 0,877 , X2 0,447 dan X3 0,510.

4. Uji Multikolineritas

Untuk menguji adanya multikolinearitas dapat dilihat melalui Variance Inflantion Factor (VIF) $<10$ dan tolerance $>0.1$. Variabel kualitas produk (X1) dengan nilai VIF 1,006, variabel harga (X2) dengan nilai VIF 2,210, dan variabel promosi (X3) dengan nilai VIF 2.217. Pada variabel kualitas produk (X1) dengan nilai tolerance 0,994, variabel harga (X2) dengan nilai tolerance 0,452 , dan variabel promosi (X3) dengan nilai tolerance 0,451. Dengan demikian dapat dikatakan bahwa tidak terdapat korelasi variabel-variabel bebas antara satu dengan yang lainnya, atau variabel independent pada penelitian ini bebas multikolineritas.

5. Uji Regresi Berganda

Dari persamaan diatas dapat diambil kesimpulan bahwa:

1. Koefisien regresi kualitas produk bernilai negatif yaitu $-0,665$. Hal ini berarti setiap peningkatan kualitas produk sebesar satu satuan akan meningkatkan keputusan pembelian adalah -0,665 satuan dengan asumsi variabel lain selain kualitas produk adalah tetap atau tidak mengalami perubahan

2. Koefisien regresi harga bernilai positif yaitu 0,030 . Hal ini berarti setiap peningkatan harga sebesar satu satuan akan mengakibatkan peningkatan keputusan pembelian adalah 0,030 satuan dengan asumsi variabel lain selain harga adalah tetap atau tidak mengalami perubahan.

3. Koefisien regresi promosi bernilai positif yaitu 0,881 . Hal ini berarti setiap peningkatan promosi sebesar satu satuan akan mengakibatkan peningkatan keputusan pembelian adalah 0,881 satuan dengan asumsi variabel lain selain promosi adalah tetap atau tidak mengalami perubahan.

6. Uji Hipotesis

Nilai $F$ hitung adalah 553,825 sedangkan nilai sig adalah 0,000. Dengan demikian berarti $\mathrm{F}$ hitung $>\mathrm{F}$ tabel dan nilai sig $<\alpha 0,05$, yaitu 553,825 $>2,72$, dan sig $0,000<\alpha 0,05$. Hal ini menunjukkan bahwa model regresi dapat digunakan untuk menguji pengaruh secara bersama-sama variabel independen terhadap variabel dependen, yaitu kualitas produk, harga dan promosi bersamasama berpengaruh terhadap keputusan pembelian.

Pengujian hipotesis 1 dilakukan dengan membandingkan nilai t hitung dan $\mathrm{t}$ tabel. Hipotesis diterima jika $\mathrm{t}$ hitung $>\mathrm{t}$ tabel atau nilai sig $<\alpha 0,05$. Nilai $\mathrm{t}$ tabel pada $\alpha=0,05$ adalah 1,984 . Untuk variabel kualitas produk (X1) nilai t hitung 
adalah 1,396 atau nilai sig adalah 0,166. Dengan demikian dapat dikatakan bahwa $\mathrm{t}$ hitung $>\mathrm{t}$ tabel, yaitu $1,396<1,984$ atau nilai signifikansi $0,166>\alpha 0,05$. Nilai koefisien $\beta$ dari variabel X1 bernilai positif yaitu 0,030 . Hal ini menunjukkan bahwa penelitian ini dapat membuktikan kualitas produk (X1) tidak berpengaruh signifikan terhadap keputusan pembelian. Sehingga hipotesis pertama pada penelitian ini tidak dapat diterima

Pengujian hipotesis 2 dilakukan dengan membandingkan nilai t hitung dan $\mathrm{t}$ tabel. Hipotesis diterima jika $t$ hitung $>t$ tabel atau nilai sig $<\alpha 0,05$. Nilai t tabel pada $\alpha=0,05$ adalah 1,984 . Untuk variabel harga (X2) nilai t hitung adalah 18,605 atau nilai sig adalah 0,000. Dengan demikian dapat dikatakan bahwa $t$ hitung $>$ t tabel, yaitu 18,605 > 1,984 atau nilai signifikansi $0,000<\alpha 0,05$. Nilai koefisien $\beta$ dari variabel X2 bernilai positif yaitu 0,881 . Hal ini menunjukkan bahwa penelitian ini dapat membuktikan harga (X2) berpengaruh signifikan terhadap keputusan pembelian. Sehingga hipotesis kedua pada penelitian ini dapat diterima

Pengujian hipotesis 3 dilakukan dengan membandingkan nilai t hitung dan $t$ tabel. Hipotesis diterima jika $\mathrm{t}$ hitung $>\mathrm{t}$ tabel atau nilai $\operatorname{sig}<\alpha 0,05$. Nilai $\mathrm{t}$ tabel pada $\alpha=0,05$ adalah 1,984. Untuk variabel promosi (X3) nilai t hitung adalah 10,569 atau nilai sig adalah 0,000. Dengan demikian dapat dikatakan bahwa $t$ hitung $>\mathrm{t}$ tabel, yaitu 10,569 $>1,984$ atau nilai signifikansi $0,000<\alpha 0,05$. Nilai koefisien $\beta$ dari variabel X3 bernilai positif yaitu 0,458 . Hal ini menunjukkan bahwa penelitian ini dapat membuktikan promosi (X3) berpengaruh signifikan terhadap keputusan pembelian. Sehingga hipotesis kedua pada penelitian ini dapat diterima

Nilai Adjusted $R$ square menunjukkan 0,945. Hal ini mengindikasikan bahwa kontribusi variabel bebas yaitu kualitas produk, harga dan promosi terhadap variabel terikat yaitu keputusan pembelian $94,5 \%$, sedangkan $15,5 \%$ ditentukan oleh faktor lain

\section{PEMBAHASAN}

Berdasarkan hasil analisis statistik dalam penelitian ini ditemukan bahwa hipotesis pertama (H1) disimpulkan bahwa kualitas produk mempunyai tidak berpengaruh signifikan terhadap keputusan pembelian. Hal ini dapat dilihat dari nilai signifikansinya yaitu 0,166 (besar dari $\alpha=0,05$ ). Ini dapat diartikan bahwa kualitas produk kepada konsumen yang membeli produk air minum dalam kemasan yang bermerek AICOS tidak begitu memperhatikan kualitas produk. Untuk memperkuat hasil penelitian maka peneliti melakukan wawancara kepada beberapa konsumen tentang kualitas produk dan alhasil dari kesimpulan jawaban konsumen adalah semua air yang berkemasan yang diproduksi oleh pabrik-pabrik besar memiliki kualitas produk yang sama.

Berdasarkan hasil analisis statistik dalam penelitian ini ditemukan bahwa hipotesis kedua $(\mathrm{H} 2)$ disimpulkan bahwa harga mempunyai pengaruh signifikan dan postif terhadap keputusan pembelian. Hal ini dapat dilihat dari nilai signifikansinya yaitu 0,000 (kecil dari $\alpha=0,05$ ). Ini dapat diartikan bahwa penentuan harga dari produk air minum dalam kemasan bermerek AICOS menjamin konsumen untuk membelinya.

Berdasarkan hasil analisis statistik dalam penelitian ini ditemukan bahwa hipotesis ketiga (H3) disimpulkan bahwa Promosi mempunyai pengaruh 
signifikan dan positif terhadap keputusan pembelian. Hal ini dapat dilihat dari nilai signifikansinya yaitu 0,000 (kecil dari $\alpha=0,05$ ). Ini dapat diartikan bahwa melakukan promosi meningkatkan konsumen untuk membeli air minum dalam kemasan bermerek AICOS.

\section{UCAPAN TERIMA KASIH}

Ucapan terima kasih untuk Bapak Febryandhie Ananda,SE,M.si selaku ketua sekolah tinggi ekonomi keuangan perbankan dan pembangunan ( STIE"KBP"Padang) beserta staf pimpinan, karyawan dan karyawati di STIE"KBP"Padang. Bapak Nazaruddin Azis, SE, MM selaku pembimbing. Bapak dan ibu Dosen STIE"KBP" padang yang telah membantu penulis selama menuntut ilmu yang bermanfaat kepada penulis selama perkuliahan. Teman teman dan pihak lain yang membantu penulis dalam menyelesaikan skripsi ini yang tidak dapat penulis sebutkan satu persatu namanya.

\section{DAFTAR PUSTAKA}

Andika, A., \& Susanti, F. (2018). Pengaruh Marketing Mix Terhadap Keputusan Pembelian Parfum di Azzwars Parfum Lubeg Padang. https://doi.org/10.31227/osf.io/upgc3

Assauri, Soyjan.2008. Manajemen produksi dan Operasi.Jakarta: LPFEUI

Assauri, Soyjan.2009. Manajemen Pemasaran Dasar,Konsep dan Strategi, Edisi Pertama Jakarta: Raja Grafindo

Aziz, N. (2019). Pengaruh Strategi Promosi Terhadap Keputusan Pembelian Yang Dimediasi Oleh Minat Beli Pada Konsumen Restoran KFC Cabang Khatib Sulaiman Padang. https://doi.org/10.17605/OSF.IO/V92TS

Basu Swasta dan Irawan.2006. Manajemen Pemasaran Modern. Yogyakarta: Libety

Fandy,Tjiptono. 2006. Manajemen Jasa. Yogyakarta: wijaya

Fifyanita Ghanimata, Mustafa Kamal. 2012. Analisa Pengatuh Harga, Kualitas, Produk Dan Lokasi Terhadap Keputusan pembelian. Diponegoro Journal of Managemen Volume 1. Nomor 2. Tahun 2012

Hidayati, R. R., \& Marlius, D. (2018). Aktivitas Promosi Dalam Meningkatkan Dana Pihak Ketiga Pada PT. Bank Perkreditan Rakyat (BPR) Batang Kapas Pesisir Selatan. https://doi.org/10.31227/osf.io/8dgqn

Jamarnis, S., \& Susanti, F. (2019). Pengaruh Harga Dan Periklanan Melalui Internet Terhadap Keputusan Pembelian Produk Sabun Merek Lux Pada Mahasiswa STIE “KBP” Padang. https://doi.org/10.31227/osf.io/xz3d8

Kotler, Philip. 2009. Manajemen Pemasaran. Jakarta: Erlangga 
Kotler dan Keller, 2009. Manajemen Pemasaran. Jilid 1. Edisi ke 13. Jakarta: Erlangga

Meidisa, C., \& Susanti, F. (2019). Pengaruh Preferensi Dan Pengetahuan Produk Terhadap Minat Menabung Masyarakat Pada Bank Nagari Unit Layanan Syariah Cabang Pasar Raya Padang. https://doi.org/10.31227/osf.io/bf7cr

Marlius, D. (2017). Keputusan Pembelian Berdasarkan Faktor Psikologis Dan Bauran Pemasaran Pada PT. Intercom Mobilindo Padang. Jurnal Pundi. Volume 1. No. 1. Hal. 57-66. https://doi.org/10.31575/jp.v1i1.9

Marlius, D. (2016). Pengaruh Bauran Pemasaran Jasa Terhadap Minat Nasabah Dalam Menabung Pada Bank Nagari Cabang Muaralabuh. https://doi.org/10.31227/osf.io/vdqgx

Mayliza, R. (2019). Pengaruh Kesadaran Merek, Asosiasi Merek Dan Perception Of Quality Terhadap Keputusan Pembelian Hospital Bed Merek Paramout Di PT. Aga Medika Utama Padang (Studi Kasus Rumah Sakit Umum Kota Padang). https://doi.org/10.17605/OSF.IO/VYQ4E

Priyanti,Y. Susanti, F. Aziz, N. (2017). Minat Beli Konsumen Toko Sepatu Bata Dipasar Raya Padang Dilihat Dari Sikap Dan Iklan. Jurnal Pundi, Vol. 01, No. 02

Susanti, F. (2015). Pengaruh Bauran Promosi Terhadap Keputusan Klien Dalam Memilih Radio Carano Sebagai Media Promosi Iklan. https://doi.org/10.31227/osf.io/b9ws7

Susanti, F. (2014). Pengaruh Tarif Iklan Terhadap Pendapatan Pada PT. Radio Swara Carano Batirai Indah Batusangkar. https://doi.org/10.31227/osf.io/dy863

Susanti, F., \& Gunawan, A. C. (2019). Pengaruh Bauran Promosi Dan Harga Terhadap Keputusan Pembelian Produk Kosmetik Maybelline Di Kota Padang. https://doi.org/10.31227/osf.io/npjqh

Sutisna. 2001. Perilaku Konsumen dan Komunikasi Pemasaran. Bandung: Remaja Rosdakarya

Undang-Undang No. 20 tahun 2008

Widayati, R. (2019). Aktivitas Pemasaran Produk Tabungan Pada PT. Bpr Rangkiang Denai Payakumbuh Barat. https://doi.org/10.17605/OSF.IO/S3UZM

Widayati, R. (2019). Aktivitas Pemasaran Produk Simpanan PT. Bank Tabungan Negara (Persero)Tbk Kantor Cabang Padang. https://doi.org/10.17605/OSF.IO/3Z5YC 